УДК 342.25

https://doi.org/10.34142/24130060.2019.17.1.19

\title{
АДМІНІСТРАТИВНО-ТЕРИТОРІАЛЬНИЙ УСТРІЙ В УКРАЇНІ: ОСНОВНІ ЕТАПИ СТАНОВЛЕННЯ ТА ЇХНІ ХАРАКТЕРИСТИКИ
}

\author{
O.В. Стогова \\ Сумський державний університет
}

Автором статті проаналізовано основні етапи становлення адміністративнотериторіального устрою Украӥни. Розглянуто основні праці, щуо досліджують ияю проблематику. Висвітлено базові характеристики основних етапів становлення адміністративно-територіального устрою, визначені їхні основні недоліки та переваги. Особливу увагу приділено періоду незалежності Украӥни. Досліджено основні нормативно-правові акти, щуо регулюють адміністративно-територіальний устрій сучасної Украӥни.

Встановлено, щчо всі спроби реформування територіальної організачії влади протягом XX cm. мали на меті створення моделі, яка є максимально зручною для управління із иентру. Кожен етап характеризується відповідністю вимогам діючої політичної системи, а не прагненням до задоволення потреб громадян.

Ключові слова: адміністративно-територіальний устрій, адміністративнотериторіальна реформа, об'єднана територіальна громада.

\section{АДМИНИСТРАТИВНО-ТЕРРИТОРИАЛЬНАЯ РЕФОРМА В УКРАИНЕ: ОСНОВНЫЕ ЭТАПЫ СТАНОВЛЕНИЯ И ИХ ХАРАКТЕРИСТИКИ}

\section{O.В. Стогова}

Автором статьи сделан анализ основных этапов становления административнотерриториального устройства Украиныл. Рассмотрено основные труды по изучению указанной проблематики. Освещено базовые характеристики основных этапов становления административно-территориального устройства, определены их основные недостатки и преимущества. Особенное внимание уделено периоду независимости Украины. Исследованы основные нормативно-правовые акты, регулирующие административно-территориальное устройство современной Украины.

Установлено, что все попытки реформирования территориальной организации власти на протяжении ХХ века своей целью ставили создание модели, максимально удобной для управления из иентра. Каждый этап характеризуется соответствием требованиям действующей политической системы, а не стремлением к удовлетворению нужд граждан.

Ключевые слова: административно-территориальное устройство, административно-территориальная реформа, объединенная территориальная громада.

(C) О.В. Стогова, 2019 


\section{ADMINISTRATIVE-TERRITORIAL REFORM IN UKRAINE: MAIN STAGES OF FORMATION AND THEIR CHARACTERISTICS}

\section{O. Stogova}

The author of the article analyzed the main stages of the formation of the administrativeterritorial structure of Ukraine. The main works on the study of these issues are considered. The author notes that the characteristics of the main stages of the formation of the administrativeterritorial division of Ukraine and the study of the influence on the current state and prospects of development remain out of researchers' attention. The basic characteristics of the main stages of the formation of the administrative-territorial structure are highlighted, the essential disadvantages and advantages are identified. Particular attention is paid to the period of independence of Ukraine. The main legal acts which regulating the administrative-territorial structure of modern Ukraine are investigated.

The analysis of the main stages of the formation of the administrative-territorial system in Ukraine makes it possible to draw the following conclusions: principles of administrativeterritorial division and its purpose during $X X$ century were fundamentally different from those which are advanced by the modern constitutional and democratic states, all attempts to reform the territorial organization of power during the twentieth century had the purpose to create a model which convenient to be managed from the center. Each stage is characterized by compliance with the requirements of the current political system, but not by the desire to meet the needs of citizens. In result of the European choice of Ukraine it was the need to introduce European standards into the system of regional and local development and the formation of effective local self-government. It has been established that the goal of the administrativeterritorial structure is to provide citizens the maximum amount of quality services by authorities at all levels of government.

Key words: administrative-territorial system, administrative-territorial reform, united territorial community.

Постановка проблеми. Адміністративно-територіальний устрій сучасної України $є$ результатом тривалого періоду формування, що розпочався ще за часів перебування українських земель у складі Російської та Австро-Угорської імперій та продовжився у складі Радянського Союзу. Принципи адміністративно-територіального поділу та його мета у державах вказаного типу кардинально відрізнялися від тих, що висуваються сучасною правовою та демократичною державою. Як наслідок, існуючий в Україні адміністративно-територіальний поділ не враховує принципів економічної доцільності та не забезпечує надання населенню максимально можливої кількість якісних послуг, що призводить до суттєвих соціально-економічних та територіальних диспропорцій.

Аналіз актуальних досліджень. Проблему реформування адміністративно-територіального устрою України розглядали вітчизняні 
вчені О. С. Власюк, В. С. Кравців, .В.Жук, М. І. Долішній, Б. М. Данилишин, Я. В. Верменіч, В. І. Шабельніков, М. С. Міхровська. Вивчаючи значний доробок вітчизняних науковців у сфері реформування адміністративно-територіального устрою України, слід відзначити, що окремо аналізується сучасний адміністративно-територіальний устрій без урахування історії його становлення, або розглядається проблематика історичного розвитку адміністративного поділу. Поза увагою дослідників залишаються характеристики основних етапів становлення адміністративнотериторіального поділу України та вивчення їхнього впливу на сучасний стан та перспективи розвитку територіальної організації влади в Україні.

Мета статті - дослідити становлення адміністративно-територіального устрою в Україні та визначити основні етапи його формування, виділити їхні переваги та недоліки, сформулювати рекомендації щодо реформування сучасного адміністративно-територіального устрою в Україні.

Виклад основного матеріалу. До 1918 року в Україні зберігався адміністративний поділ Російської імперії: губернія-повіт-волость. Для забезпечення принципу народоправства в УНР М. Грушевський розробив проект ліквідації старого імперського поділу та запровадження нового, який мав бути представлений землями, меншими за колишні губерніі, але більшими за повіти.

6 березня 2018 р. «Закон про поділ України на землі» був ухвалений Малою радою. Відповідно до цього закону, територія УНР поділялася на 32 землі, також передбачалося, що середня кількість населення однієї землі мала б складати біля 1 млн. осіб. Цей адміністративний поділ не був реалізований на практиці, адже невдовзі гетьман П. Скоропадський повернув старий адміністративний устрій, додавши до нього новоутворені Таврійський та Поліський округи. На території ЗУНР у цей період зберігався старий австрійський поділ на округи (Шабельніков, 2011).

Директорія здійснювала адміністративний контроль своєї території на підставі закону «По організацію адміністративної влади УНР», яким 
територія республіки поділялася на Західну і Східну області, а Східна область поділялася на 9 губерній (Верменич, 2009).

Із встановленням влади більшовиків почалися докорінні зміни у адміністративно-територіальному устрої українських земель. Постановою ЦК РКП(б) від 15 березня 1918 року Донецький басейн був визнаний територією України (Шабельніков, 2011). Відповідно до положення уряду Радянської України про організацію місцевих органів влади і управління від 30.11.1918 p. на місцях почали масово створювати сільські ради навіть у найменших селах, а губернії, повіти та волості поки зберігалися. Можна зробити висновок, що основна увага радянської влади була зосереджена саме на найнижчому адміністративному рівні. Найпомітнішими змінами цього періоду у територіальній організації влади стали: утворення Донецької губернії із центром у м. Бахмут, відокремлення від Херсонської губернії Одеської. Крім того, були створені Кременчуцька та Олександрівська (Запорізька) губернії, які проіснували до 1922 р. та Кримська АРСР. Певних змін зазнав і повітовий поділ.

Наприкінці 1922 року Всеукраїнський центральний виконавчий комітет УСРР своєю постановою затвердив нові принципи адміністративнотериторіального устрою республіки. 12 квітня 1923 р. повіти і волості скасовувалися та запроваджувався новий адміністративно-територіальний устрій: губернія-округа-район-сільрада.

Округів стало майже вдвічі менше ніж було повітів, районів майже втричі менше ніж волостей. Сільські ради також укрупнювалися, адже 3 кінця 1918 року їх організовували у найменших селах. Змінювалися межі районів, округ, губерній, створювалися адміністративні одиниці для національних меншин у місцях їхнього компактного проживання. У складі УСРР була створена Молдавська АСРР.

19 лютого 1925 р. постановою ВУЦВК були скасовані губернії та впроваджувався новий адміністративний поділ: округа-район-сільрада. На 1 серпня 1925 р. територія УСРР поділялася на 1 автономну республіку 
(Молдавську АРСР) і 41 округу, які у свою чергу ділилися на 680 районів, 10314 сільських рад, 7 міських та 155 селищних рад. Округова система проіснувала у вказаному вигляді до вересня 1930 р., коли округи були ліквідовані та впроваджена нова територіальна організація влади: центррайон-місцева рада. 315 вересня 1930 р. запроваджувався наступний адміністративний поділ республіки: 1 автономна республіка, 18 міст та 484 райони. Але 119 районів були ліквідовані шляхом приєднання їхніх територій до інших районів вже протягом наступного 1931 року як неефективні, і в результаті залишилося всього 365, які прямо підпорядковувалися центру. Характерною рисою цього етапу можна назвати саме відсутність проміжної ланки між центром та районом, тобто центральній владі прямо підпорядковувалися 365 районів.

Такий поділ проіснував недовго, райони не виправдали себе у якості адміністративної одиниці найвищої ланки і вже 1932 року ВУЦВК постановила утворити на території УСРР 5 областей, а саме: Харківську, Київську, Дніпропетровську, Одеську та Вінницьку, які і мали взяти на себе функцію посередника між центром та районами. Наприкінці цього ж року були утворені Чернігівська та Донецька області. Далі утворення областей продовжилося, і з 1937 по 1939 рр. були створені Полтавська, Житомирська, Кам'янець-Подільська, Миколаївська, Ворошиловградська, Сумська, Кіровоградська та Запорізька області (Шабельніков, 2011).

Обласна структура, на якій у 1932 р. зупинилися реорганізації територіального устрою, була фактично лише погіршеною копією колишньої губернської. Але незаперечним позитивним наслідком бурхливих адміністративно-територіальних реформ 20-30-х рр. можна вважати встановлення міжреспубліканських кордонів. Встановлені часто ситуативно, без урахування економічних зв'язків, що історично склалися та нехтуючи думкою населення, саме ці кордони у 1991 році забезпечили територіальну основу відносно безболісного розпаду СРСР та створення нових суверенних республік. 
Унаслідок приєднання до УРСР території Західної України, Північної Буковини та частини Бессарабії, були створені Волинська, Ровенська, Львівська, Тернопільська, Станіславська, Дрогобицька, Чернівецька та Акерманська (Ізмаїльська) області. 30 березня 1944 році була створена Херсонська, а 22 січня 1946 року Закарпатська області. Таким чином, на 1 вересня 1946 року у складі УРСР було 25 областей, 750 районів та 13 округ у Закарпатті.

Протягом 1954 р. Україні була передана Кримська область, ліквідована Ізмаїльська та утворена Черкаська область. Кримську область було передано зі складу РРФСР до складу УРСР 19 лютого 1954 р. згідно з Указом Президії Верховної Ради СРСР. Передачу здійснили, ураховуючи територіальну близькість і тісні господарські та культурні зв'язки між Кримською областю та Українською РСР. Передачу було приурочено до святкування 300-річчя Переяславської Ради. Місто Севастополь, як місто республіканського підпорядкування, передано не було.

31954 по 1960 рік були черговий раз укрупнені сільські ради та райони, у результаті залишилося 611 районів. Крім того, 1959 р. було ліквідовано Дрогобицьку область.

Так, станом на 1960 р. в УРСР було 25 областей, 611 районів, 85 міст обласного підпорядкування, 8741 сільська рада та 781 селищна рада. Адміністративно-територіальний устрій УРСР набув певної одноманітності, структурованості та завершеності на всій території республіки.

Але після Указу Президії Верховної Ради УРСР від 30 грудня 1962 р. «Про укрупнення сільських районів УРСР» протягом 1962-63 pp. радянські органи були реорганізовані за ініціативою М. Хрущова за виробничим принципом, унаслідок чого станом на квітень 1963 р. в УРСР залишалося 25 областей, але вже 251 сільський район та 2 промислових райони. Після відставки Хрущова у листопаді 1964 р. частина районів була знову розукрупнена та їх стало 475. 
Вказані реформи адміністративно-територіального устрою призвели до скорочення кількості адміністративних одиниць і заклали підвалини регіонального розвитку за участі місцевої влади.

Конституція УРСР 1978 р. закріпила принцип централізму у здійсненні державної влади та поділ на 25 областей. Глава 8 Конституції УРСР визначала адміністративно-територіальний устрій Української РСР. У Ст. 76 зазначалося, що віданню Української Радянської Соціалістичної Республіки підлягає визначення обласного, районного поділу і вирішення інших питань адміністративно-територіального устрою республіки. А Ст. 77 перераховувала назви 25 областей та вказувала, що містами республіканського підпорядкування в Українській РСР є Київ і Севастополь, таким чином врегульовувалася ситуація із Севастополем, який 1954 р. не був переданий у підпорядкування до УРСР.

Територіальна організація влади, закладена у 70-х роках $\mathrm{XX}$ ст. зберіглася до 90-х pp. та була успадкована незалежною Україною. Детальніше територіальний поділ УРСР цього періоду регламентувався Указом Президії Верховної ради Української РСР «Про порядок вирішення питань адміністративно-територіального устрою Української РСР» від 12 березня 1981 року. Відповідно до вказаного нормативно-правового акту адміністративно-територіальними одиницями Української РСР зазначалися: область, район, місто, район у місті, селище міського типу, сільрада, село і селище. Встановлювався порядок утворення районів, областей, а також перейменування населених пунктів.

Значна зміна у адміністративно-територіальному поділі УРСР відбулася 12 лютого 1991 р., коли за результатами референдуму, проведеного 20 січня 1991 р., Кримська область була перетворена у Кримську АРСР у складі УРСР.

Необхідність реформування адміністративно-територіального устрою України була зрозумілою одразу після проголошення незалежності у1991р., однак наявність більш гострих політичних, ідеологічних та економічних 
проблем і неможливість реформувати одразу всі сфери відклали це питання у часі.

Ухвалений Верховною Радою України 1997 р. законопроект «Про адміністративно-територіальний устрій України» був заветований президентом.

Концепція адміністративно-територіальної реформи, прийнята 1998 р. залишилася на папері і реалізована не була.

Знову до проблеми адміністративного устрою повернулися 2005 р., коли була створена робоча група на чолі із прем'єр-міністром Р. Безсмертним. Важливо, що авторами проекту реформи крім загальних принципів іï проведення були запропоновані і конкретні кількісні показники: так, громада мала складатися не менш ніж 35 тисяч жителів, район - 70 тисяч, регіон - 750 тисяч. Крім того, передбачалося максимально реалізувати принципи субсидіарності та делегування повноважень органам місцевого самоврядування (Безсмертний, 2005). Але цей проект реформи під час публічного обговорення зазнав значної критики та спротиву з боку місцевих еліт. Для вдосконалення проекту та реалізації реформи не вистачило політичної волі, хоча більшість науковців та практиків із державного управління та місцевого самоврядування погоджувалися, що основними недоліками діючої територіальної організації влади були наступні: невиправдана централізація управління, помітна нерівномірність у розвитку регіонів, дублювання повноважень виконавчої влади та місцевого самоврядування на рівні району та області. Але основною проблемою визнавали наявність надмірної кількості нечисельних територіальних громад, що не мали власної організаційної та матеріально-фінансової бази для здійснення реального самоврядування.

Знову до проблеми реформування адміністративно-територіального устрою повернулися у 2014 р. після схвалення Концепції реформування місцевого самоврядування та територіальної організації влади в Україні. На початок реформи в Україні було 24 області і АРК, які у свою чергу 
поділялися на 490 районів. Концепція залишає трирівневий поділ: громада район - регіон, але із перерозподілом повноважень на рівень громади, що вимагає створення потужних самодостатніх територіальних громад.

Тому наступним етапом реформи стало прийняття Закону України «Про добровільне об’єднання територіальних громад», який створив правову основу для формування базового рівня місцевого самоврядування на нових принципах. За основу формування адміністративно-територіальної одиниці базового рівня береться центр економічного тяжіння, а не населений пункт із наявними інфраструктурними перевагами, як передбачалося проектом реформи 2005 p.

Наступним етапом у проведенні реформи територіальної організації влади стало схвалення Урядом Проекту Закону про засади адміністративнотериторіального устрою України № 8051 від 22.02.2018 р.

Цей законопроект законодавчо врегульовує питання щодо порядку утворення, ліквідації, встановлення та зміни меж адміністративнотериторіальних одиниць, назв населених пунктів та віднесення їх до певних категорій. Зберігається трирівнева система адміністративно-територіального устрою України - регіональний рівень (АР Крим і області), субрегіональний рівень (райони) та базовий рівень - громади, до складу яких входять один або декілька населених пунктів.

Ст. 5 законопроекту дає визначення та ознаки адміністративнотериторіальної одиниці. Передбачені адміністративно-територіальні одиниці регіонального, субрегіонального, базового та допоміжного рівнів.

Ст. 7 визначає поняття громада та регламентує місце знаходження iii адміністративного центру. У Ст. 8 визначено поняття району та вказані кількісні вимоги для його утворення - 150 тис. мешканців. Але ця норма законопроекту викликає питання, адже у більшості областей України вже затверджені госпітальні округи і до них висувалася у тому числі і вимога мінімум 120 тисяч населення (ст. 11). Зрозуміло, що укрупнення районів, яке найближчим часом має розпочатися в Україні мало б бути проведено 
відповідно до створених госпітальних округів. Але мінімальні кількісні вимоги до району та госпітального округу різняться на 30 тисяч осіб. Тому не зовсім зрозуміло, яким стандартам буде надана перевага при укрупненні округів.

Проектом Закону про засади адміністративно-територіального устрою України № 8051 (п.2 ст. 8) визначено, що район є територіальною основою організації та діяльності місцевого органу виконавчої влади, територіальних органів центральних органів виконавчої влади та органу місцевого самоврядування району. Таке визначення прямо відповідає напряму реформування місцевого самоврядування в Україні відповідно до Концепції, адже усувається дублювання функцій районної державної адміністрації 3 органами місцевого самоврядування ОТГ.

Важливим нововведенням є передбачена законопроектом державна реєстрація адміністративно-територіальних одиниць. Крім того, відповідно до п.4.ст.12, відомості про межі адміністративно-територіальних одиниць $є$ обов’язковими для внесення до Державного земельного кадастру у порядку, визначеному Кабінетом Міністрів України.

Важливим недоліком у проведенні добровільного об’єднання територіальних громад експерти вказували відсутність мінімальних кількісних вимог. У відповідь ст. 14. вказаного законопроекту регламентує мінімальну кількість населення у громаді, так п. 4. вказує, що мінімальна розрахункова кількість населення сільської громади визначається Кабінетом Міністрів України, а менша чисельність населення допускається для сільських громад, розташованих на важкодоступних територіях. П.5. регламентує мінімальну площу сільської громади, вона має бути не меншою за половину середньої по Україні площі сільських громад, крім важкодоступних територій та прикордонних районів, де площа громади не може бути меншою за третину середньої по Україні площі сільських громад.

Висновки і перспективи подальших досліджень. Аналіз основних етапів становлення адміністративно-територіального устрою в Україні 
дозволяє зробити наступні висновки: всі спроби реформування територіальної організації влади протягом XX ст. мали своєю метою створення моделі, яка є максимально зручною для управління із центру. Кожен етап характеризується відповідністю вимогам діючої політичної системи, а не прагненням до задоволення потреб громадян. Результатом європейського вибору України стала необхідність запровадження європейських стандартів у систему управління регіональним і місцевим розвитком та розбудови ефективного місцевого самоврядування. Тому метою реформування місцевого самоврядування та територіальної організації влади в Україні на даному етапі має стати надання реальної можливості для людини отримати максимальну кількість якісних послуг від органів влади на кожному рівні управління. Реальним кроком у цьому напряму має стати прийняття Закону України Закону про засади адміністративнотериторіального устрою України.

\section{ЛІТЕРАТУРА}

1. Безсмертний, Р. Основні засади адміністративно-територіальної реформи в Украӥні. [online] Доступно: http://www.adm.dp.ua/OBLADM/Obldp.nsf/b19e47826f35603ec2256f29003c32ff/60e3a2 1fd141cd61 c22571aa0027dbeb [Дата звернення 19 січень 2019].

2. Верменич, Я.В. 2009. Адміністративно-територіальний устрій Украйни: еволючія, сучасний стан, проблеми реформування. Ч. 1. Київ: Інститут історії України.

3. Верменич, Я.В. 2009. Адміністративно-територіальний устрій України: еволюиія, сучасний стан, проблеми реформування. Ч. 2. Київ: НАН України. Інститут історії України.

4. Верховна Рада України, 2019. Конституиія УРСР 1978 р. [online] Доступно: http://gska2.rada.gov.ua/site/const/istoriya/1978.html [Дата звернення 19 січень 2019].

5. Верховна Рада України, 2019. Про порядок вирішення питань адміністративнотериторіального устрою Украйнської РСР: Указ Президї Верховної Ради Української РСР від 12 березня 1981 p. № 1654-X. [online] Доступно: http://zakon4.rada.gov.ua/laws/show/1654- [Дата звернення 19 січень 2019].

6. Верховна Рада України, 2019. Про схвалення Концепиії реформування місиевого самоврядування та територіальної організаџії влади в Україні: Розпорядження Кабінету Міністрів України від 1 квітня 2014 р. № 333-p. [online] Доступно: http://zakon4.rada.gov.ua/laws/show/333-2014-\%D1\%80 [Дата звернення 19 січень 2019].

7. Верховна Рада України, 2019. Про засади адміністративно-територіального устрою України: проект Закону Украӥни № 8051 від 22.02.2018 p. [online] Доступно: http://w1.c1.rada.gov.ua/pls/zweb2/webproc4_1?pf3511=63508 [Дата звернення 19 січень 2019]. 
8. Верховна Рада України, 2019. Про затвердження порядку створення госпітальних округів: постанова Кабміну від 30 листопада 2016 р. № 932. [online] Доступно: https://zakon.rada.gov.ua/laws/show/932-2016-\%D0\%BF [Дата звернення 19 січень 2019].

9. Власюк, О.С., 2015. Стан і проблеми реформування адміністративнотериторіального устрою України. Регіональна економіка, 3, с.16-23.

10. Данилишин, Б.М., 2015. Як децентралізувати управління в Україні. Економічна правда, 15 Лип. Доnline] Доступно: https://www.epravda.com.ua/columns/2015/07/13/550472/ [Дата звернення 19 січень 2019].

11. Долішній, M.І., 2011. Проблеми територіального устрою в системі адміністративної реформи. В: М.I. Долішній, ред. Мар'ян Іванович Долішній - Вчений, Керівник, Особистість. Львів: НАН України. Інститут регіональних досліджень, с. 100.

12. Державний архів Київської області, 1918. Закон про поділ України на землі. [online] Доступно: http://dako.gov.ua/українська-соборність-витоки/ [Дата звернення 19 січень 2019].

13. Кравців, В.С. та Жук, П.В., 2011а. Адміністративно-територіальний устрій та місцеве самоврядування в Україні: питання реформування. Бюлетень Західного наукового центру, с. 130-144.

14. Кравців, В.С. та Жук, П.В., 2011b. Концепція адміністративно-територіальної реформи в Україні. Економіст, 5, с. 5-8.

15. Міхровська, М.С., 2019. Адміністративна реформа в Україні аналіз, періодизація та перспективи. Адміністративне право $i$ процес. [online] Доступно: http://applaw.knu.ua/index.php/arkhiv-nomeriv/4-10-2015/item/348-administratyvnareforma-v-ukrayini-analiz-periodyzatsiya-ta-perspektyvy-mikhrovska-m-s [Дата звернення 19 січень 2019].

16. Шабельніков, В.І. 2011. Адміністративно-територіальний устрій України: історичний досвід і уроки (1917 - червень 1941 рр.). Донецьк: ДонНУ.

\section{Інформація про автора}

Стогова Ольга Володимирівна - кандидат політичних наук, доцент, доцент кафедри конституційного права, теорії та історії держави і права Навчально-наукового інституту права Сумського державного університету; e-mail: o.stohova@uabs.sumdu.edu.ua; ORCID: http://orcid.org/0000-0001-7010-556X.

Стаття надійшла до редакції: 23.01.2019 р. Прийнята до друку: 04.02.2019 р. 